\title{
Sperm competition in Odonata (Insecta): the evolution of female sperm storage and rivals' sperm displacement
}

\author{
A. Córdoba-Aguilar ${ }^{1 *}$, E. Uhía ${ }^{2}$ and A. Cordero Rivera ${ }^{2}$ \\ ${ }^{1}$ Instituto de Ecología, Universidad Nacional Autónoma de México, Apdo. Postal 70-275, Circuito exterior Ciudad Universitaria 04510, Mexico, D.F. \\ ${ }^{2}$ Grupo de Ecoloxía Evolutiva, Departamento de Ecoloxía e Bioloxía Animal, Universidade de Vigo, E.U.E.T. Forestal, Campus Universitario, \\ 36005 Pontevedra, Spain
}

(Accepted 2 June 2003)

\begin{abstract}
Odonates (dragonflies) are well known for the ability of the males to displace sperm stored in the female's spermstorage organs during copulation. By this means, copulating males are able to increase their fertilization success. This ability has been used as an example to illustrate a conflict of interests between the sexes in which males have evolved sperm-displacement mechanisms whilst females have presumably evolved means to avoid sperm displacement. The present review has four aims: (1) to describe the copulatory mechanisms used during sperm displacement; (2) to analyse the causes of sperm usage patterns; (3) to discuss this information using current hypotheses on conflict between the sexes; (4) to illuminate topics for further research. Four copulatory mechanisms are described: sperm removal (physical withdrawal of stored sperm), sperm repositioning ('pushing' of rival sperm to sites where its use will be least likely), female sensory stimulation to induce sperm ejection, and sperm flushing (displacement of sperm using the copulating male's sperm). Sperm-precedence studies in Odonata are scarce and their values vary considerably between species. In those species in which sperm displacement is incomplete, the last copulating male obtains a high but variable short-term fertilization success which decreases with time. Some male and female factors affecting sperm precedence patterns are mentioned: (1) male variation in genital morphology; (2) duration of copulation influenced by the male (the longer the copulation, the more stored sperm displaced); (3) adaptations of the sperm-storage organs that allow the female to manipulate the sperm she has received (i.e. avoiding sperm displacement, re-distributing sperm masses, favouring sperm located in certain sites and ejecting sperm after copulation). We suggest that male and female odonates have co-evolved at the level of genital function with the control of stored sperm as the focus of the conflict. The benefits for males in this co-evolution lie in maximizing their fertilization success. However, it is not clear what females obtain from storing sperm and making it unreachable during sperm displacement. Two hypothetical benefits that females may obtain for which some evidence has been gathered are genetic diversity and viability genes. It is finally suggested that odonates can become excellent subjects of study for testing current ideas related to sexual conflict and speciation processes through sexual selection.
\end{abstract}

Key words: sperm competition, sexual conflict, Odonata, copulatory mechanisms, multiple mating

\section{INTRODUCTION}

Sperm competition, the competition between the sperm of different males for fertilizing a female's set of ova (Parker, 1970), is an ubiquitous and widespread phenomenon in animal reproduction (Smith, 1984; Birkhead \& Møller, 1998). Investigation during the last 30 years has shown that sperm competition has shaped several male morphological, physiological and behavioural traits directed either to withstand the competitive abilities

*All correspondence to: A. Córdoba-Aguilar.

E-mail: acordoba@uaeh.reduaeh.mx of other males during competition or to avoid sperm competition completely.

Odonates, which comprise three suborders, Zygoptera (damselflies), Anisoptera (dragonflies) and Anisozygoptera (intermediate; common in fossils, but with only two living species), are one of the animal groups in which sperm competition has been more intensively studied and whose copulatory mechanisms are better understood (Simmons \& Siva-Jothy, 1998; Corbet, 1999; Simmons, 2001; Cordero Rivera, 2002). Like other insects, female odonates store sperm in specialized organs, delay oviposition and mate multiply. These characteristics have set the conditions for sperm competition to take place (Parker, 1970; Waage, 1984). The evidence from several 
species has shown that odonate males have evolved a series of adaptations to avoid or ameliorate the risk of their sperm competing directly with those of conspecific males (Corbet, 1999). These adaptations can occur both during and after copulation. During copulation and using a variety of mechanisms, the specialized genitalia of male odonates displace the sperm stored by the female before sperm transfer. After copulation, males engage in different sorts of female-guarding behaviour during oviposition that prevents females from re-mating.

Interaction between the sexes during reproduction has an intrinsic conflict at its basis: males and females differ in how much each invests in reproduction (Trivers, 1972; Parker, 1984). Since females are usually the sex that invests more, they try to keep control of their reproductive decisions, choosing carefully with which individuals to mate while males are under intense selection to mate (Parker, 1984). Given this difference-of-interests scenario, a co-evolutionary interaction would be expected between the sexes favouring adaptations to optimize fertilization success (Rice, 1996). How profoundly the sexual conflict of interests has shaped animal behaviour, physiology and morphology and how much such conflict has affected female reproductive decisions are renewed paradigms in sexual selection.

In his pioneering studies, Waage $(1984,1986 a)$ demonstrated the widespread and pervasive nature of the mechanisms of sperm displacement occurring in different odonate taxa. Since these works, many more studies have been published on the same or related subjects (e.g. reproductive anatomy and physiology, fertilization events, among others). Many of these studies, however, have not been analysed using a sexual selection framework. This study has four aims: (1) to describe the copulatory mechanisms and genital traits involved in spermdisplacement mechanisms; (2) to illustrate and discuss the range and causes of variation in odonate sperm precedence; (3) to analyse this information into the context of recent theoretical discussions on sexual conflict theory; (4) to highlight topics that deserve further research.

\section{COPULATORY MECHANISMS}

\section{Generalities of copulation in odonates}

Odonates have a peculiar and unique form of copulation. Female genitalia (sperm-storage organs (hereafter SSOs) and fertilization apparatus) are located between the eighth and ninth abdominal segments. In males, the primary genitalia (where sperm are produced) have an opening at the ninth abdominal segment while the secondary genitalia (the intromittent apparatus) are located on the second and third abdominal segments. Before copulation, the male grasps a female by using his abdominal appendices (at the end of the abdomen) on her prothoracic, mesostigmal plates (Zygoptera) or head (Anisoptera). Following this (as occurs in most odonate species; Corbet, 1999) the male transfers his sperm from the primary to the secondary
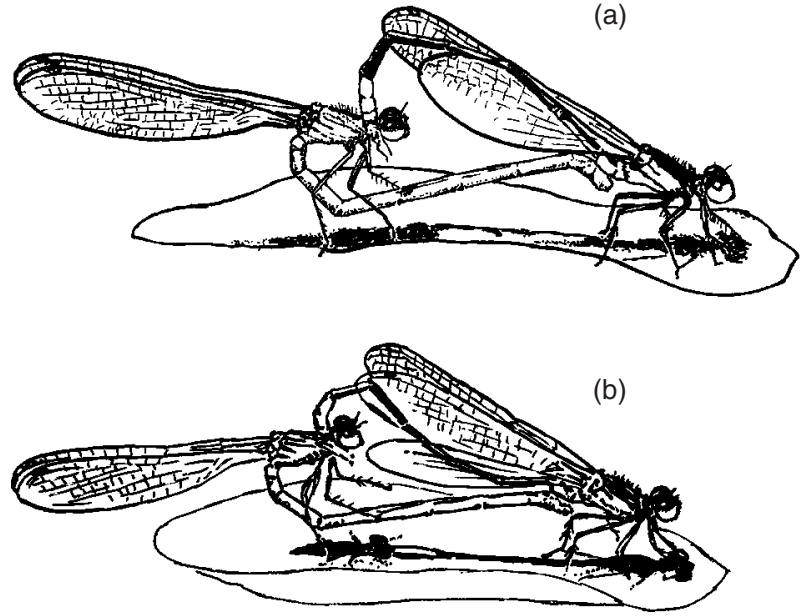

Fig. 1. The stages of copulation in Odonata: (a) stage I, during which sperm displacement takes place; note the elevation of the male abdomen; (b) stage II, insemination. Drawings by A. Cordero from slides of Erythromma viridulum copulation.

genitalia. Once grasped and for copulation to take place, females must bend their abdomen forward to make genital contact.

Copulation can be divided into two or three behavioural stages each of which is correlated with the internal genital processes (Miller \& Miller, 1981). Unlike anisopterans, the behaviour carried out by the couple in each of these stages is clearly distinguishable in Zygoptera (Waage, 1979; Miller \& Miller, 1981; Cordero, 1989; Siva-Jothy \& Tsubaki, 1989; Sawada, 1995). Stage I(Fig. 1) is the longer and more variable phase of copulation (Miller, 1987a; Cordero, 1990; Córdoba-Aguilar, 1992; Sawada, 1995; Cordero \& Andrés, 1999). The evidence from numerous species indicates that males displace sperm during this stage and inseminate during stage II (and sometimes also during stage III, Corbet, 1999).

\section{Terminology and description of genitalia}

The terminology used by different workers studying odonate genitalia is not uniform. Here we use that proposed by Pfau (1971). The accounts presented were mainly taken from the following references: Pfau (1971), Srivastava \& Srivastava (1986), Siva-Jothy (1987a), Michiels (1989), Miller (1990, 1991), Andrew \& Tembhare (1996) and Córdoba-Aguilar (2003a).

\section{Zygoptera}

\section{Males (Fig. 2)}

The seminal vesicle, a flask-like structure which stores sperm before ejaculation, is found anteriorly to the intromittent organ, on the third abdominal segment. 


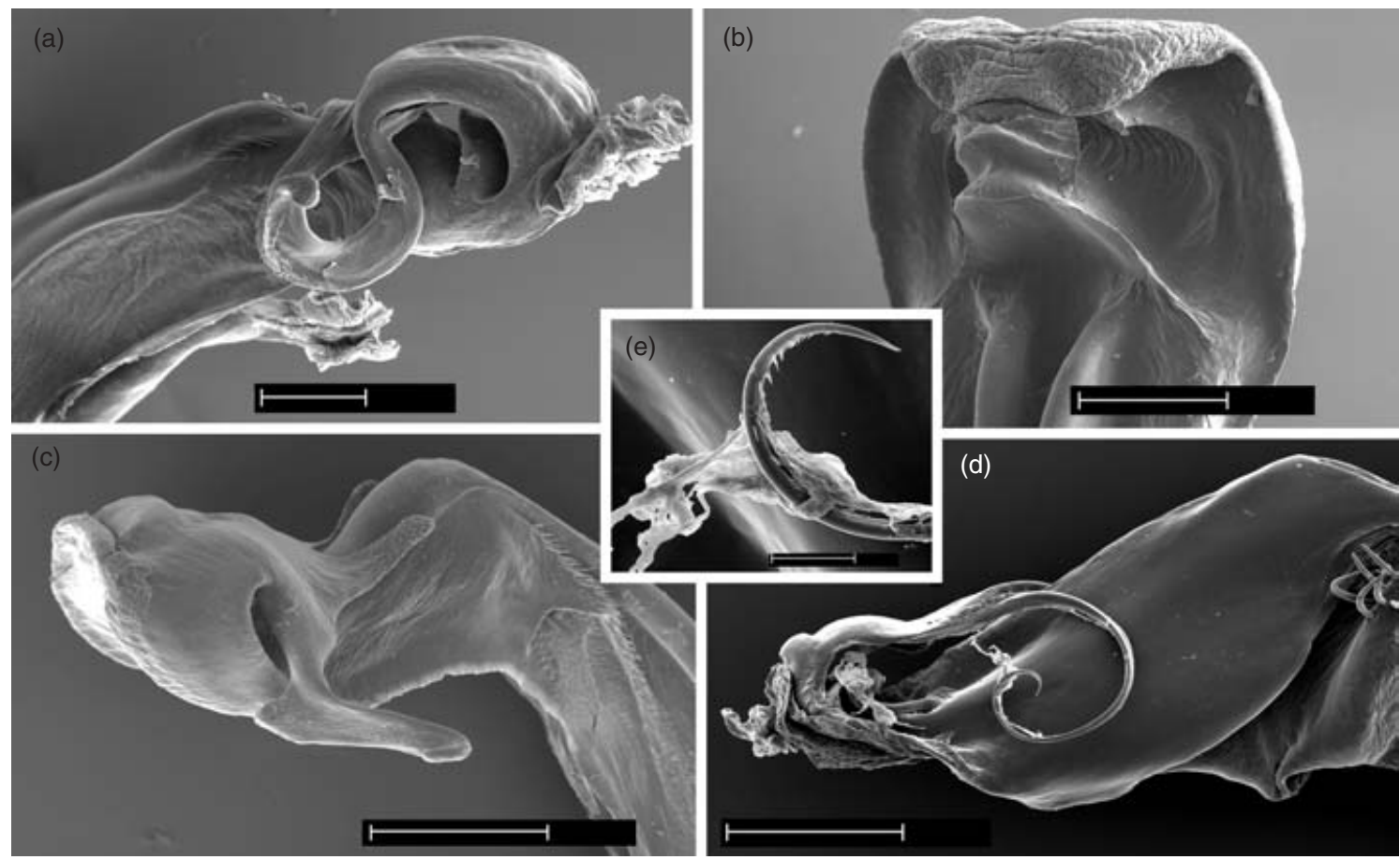

Fig. 2. Four examples of penis morphology in Zygoptera observed with SEM: (a) Calopteryx haemorrhoidalis asturica, showing one of the lateral appendages; (b) Lestes dryas; as is usual in Lestes, there are no appendages to help in sperm removal; (c) Platycnemis acutipennis, whose penis head has four small appendages; (d) Ischnura elegans, the penis head has two thin lateral processes that help remove the sperm of rivals; (e) a detail of the sperm mass removed during stage I of copulation.

The aedeagus, the intromittent organ, located on the second abdominal segment, is covered by the anterior lamina (an extension of the second abdominal sternite). The aedeagus is a curved, heavily-sclerotized structure which is proximately connected to flexible frames, a set of hamuli, and a glandular sac. Both the frames and the hamuli, along with the tergosternal muscles associated with these structures, allow the aedeagus to move during copulation. Ventral to the aedeagus is an inflatable membrane which runs longitudinally. The elastic properties of the membrane serve as a channel during sperm transfer. Distally there is the structure associated with sperm displacement, the penis head.

The penis head shows considerable variation among species (Fig. 2). Waage (1984, 1986a) classified four major types of penis head morphology according to its complexity. The Lestes penis, a ram-like structure with no distal appendages or spines (structures associated with mechanical sperm displacement; (Waage, 1979; Miller, 1987a); the Enallagma penis, a flap structure which has spines on its ventral side; the Calopteryx penis, a structure bearing two lateral horn-like appendages covered with spines; and the Argia-Ischnura penis which ends with one (Argia) or two (Ischnura) distally-curved appendages covered with spines. Notwithstanding this classification, there are species whose penis heads seem to be intermediate between these types. One example is the penis head of the neotropical genus Hetaerina, which seems intermediate between the Calopteryx and
Enallagma types, having a flap ending in two short, not heavily-curved appendages (A. Córdoba-Aguilar, pers. obs.).

\section{Females (Fig. 3)}

The zygopteran female genitalia consist mainly of the SSOs and the fertilization apparatus (vagina, vaginal plates, eighth abdominal segment ganglion), all of which are located at the eighth and ninth abdominal segments. The SSOs are sac-like structures whose function is to keep the sperm viable, as suggested by histological studies (Andrew \& Tembhare, 1996; Córdoba-Aguilar, 2003a). Two types of SSOs are usually present: the bursa copulatrix (hereafter called bursa) and the spermatheca(e). The bursa communicates directly and ventrally to the vagina and dorsally to the spermatheca. Anterior to the vaginal contact to the bursa and along the vagina, two sclerotized plates are found. These plates have a series of embedded campaniform sensilla, whose primary function is to communicate, via the eighth abdominal segment ganglion, the presence of an egg to the muscles that surround the SSO during fertilization (Miller, 1987a; Córdoba-Aguilar, 2003a). These muscles induce the contractile activity and the release of sperm stored in the SSO. Interestingly, the number of sensilla is a variable trait across species (for example, in the Calopterygidae family; Córdoba-Aguilar, 1999a, 2003b). 

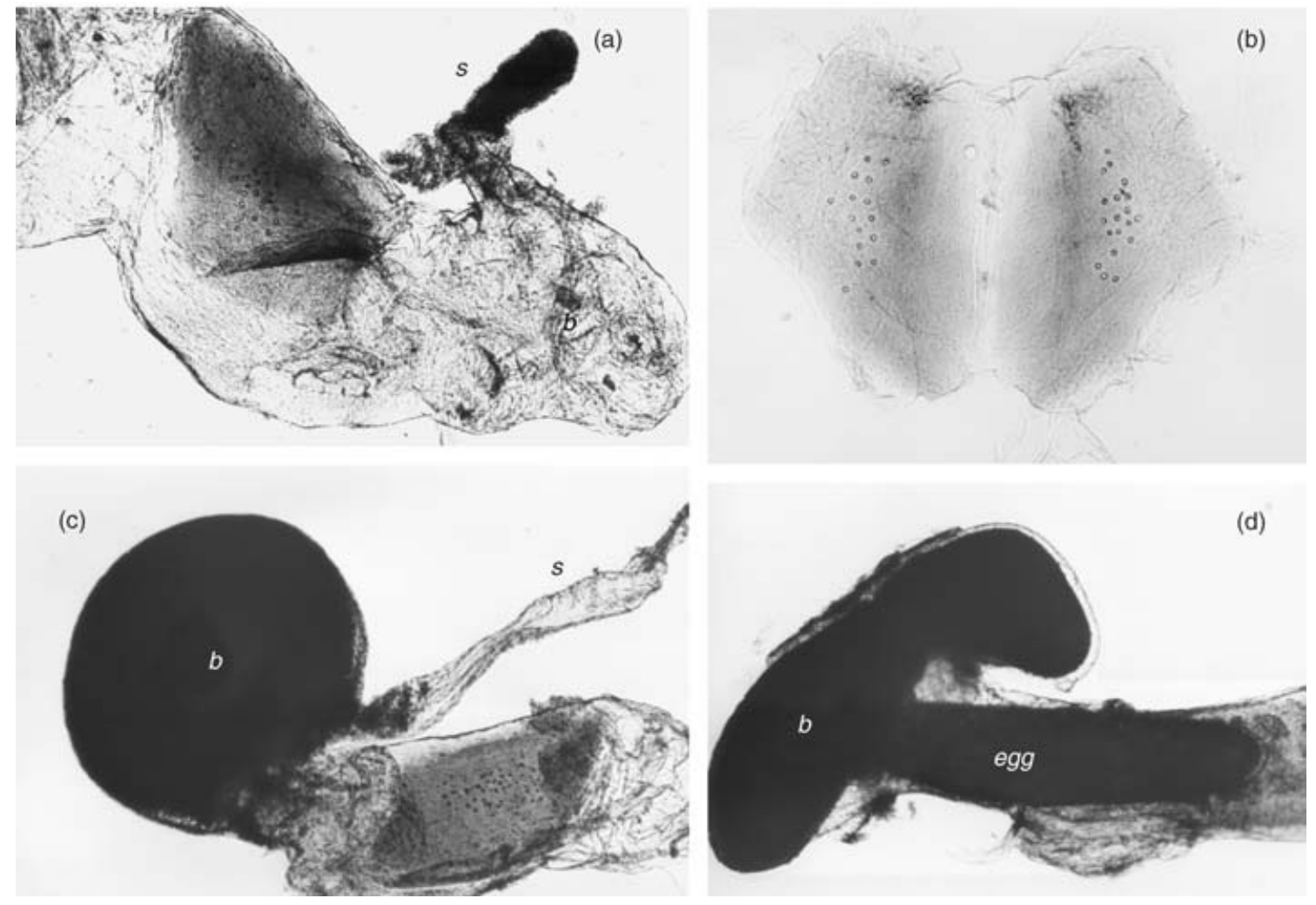

Fig. 3. Female genitalia in Zygoptera: (a) Calopteryx h. haemorrhoidalis showing the vaginal plates, bursa (b) and spermathecae (s); the bursa and the left spermatheca are empty; (b) vaginal sensilla of C. h. haemorrhoidalis; (c) Platycnemis acutipennis, the spermathecae (s) opens at the base of the bursa (b); (d) Lestes virens with a single sperm storage organ (b) and one egg in the fertilization process.

The morphology of the SSO shows clear correspondence with that of the penis head but nevertheless seems less diverse. The complexity of SSOs also increases with types of penis in different taxa as found by Waage (1984, $1986 a$ ). For example, whereas the female representative of the Lestes type does not have a defined spermatheca but only a large bursa, females of the Calopteryx type bear two enlarged and curved spermathecal ducts. It is interesting to note that some species show intra-population variation in the number of spermathecae, like Calopteryx haemorrhoidalis with generally two but sometimes only one spermatheca (A. Cordero Rivera, pers. obs.). Three characteristics of the SSO are worth mentioning: (1) the variation in form and volumetric capacity of both the bursa and the spermatheca; (2) the presence and absence of spermatheca; (3) the number of spermathecal ducts.

\section{Anisoptera}

\section{Males (Fig. 4)}

Unlike the zygopteran penis, the anisopteran intromittent organ is a four-segmented structure and far more complex. The second and third abdominal sternite (anterior lamina) and tergite (genital lobes) correspondingly, are extended to cover the penis. The penis is a sperm-storage organ homologous to the zygopteran sperm vesicle (Miller,
1990) that is folded when in rest. The sperm are internally stored in all segments in an internal canal with two openings to the outside. During copulation, segment 1 expands, while segments 2, 3 and 4 extend fully. Segment 4 shows remarkable interspecific variation, possibly owing to its sperm-displacement function (Miller, 1991). Different inflatable lobes and structures are attached to this segment: lateral lobes, apical lobes, inner lobes, a flagellum and cornua. Among possible functions of these structures are: anchoring the entry of the SSO by the cornua (Michiels, 1989) and lateral and apical lobes (Miller, 1991); spermathecal sperm removal by the flagellum, medial process and the cornua (Miller, 1991); and penetration to the bursa to push stored sperm to places far from the fertilization site by the medial lobes (SivaJothy, 1988).

\section{Females (Fig. 5)}

Genitalia of female anisopterans are less complex than anisopteran male genitalia but nevertheless more diverse than those of zygopterans. The genitalia involve a bursa, a pair of spermathecal ducts, an opening to the vagina, a pair of lateral, vaginal, longitudinally-arranged plates, and an eighth abdominal segment ganglion. These structures are similar in function and in arrangement to those of the Zygoptera. 

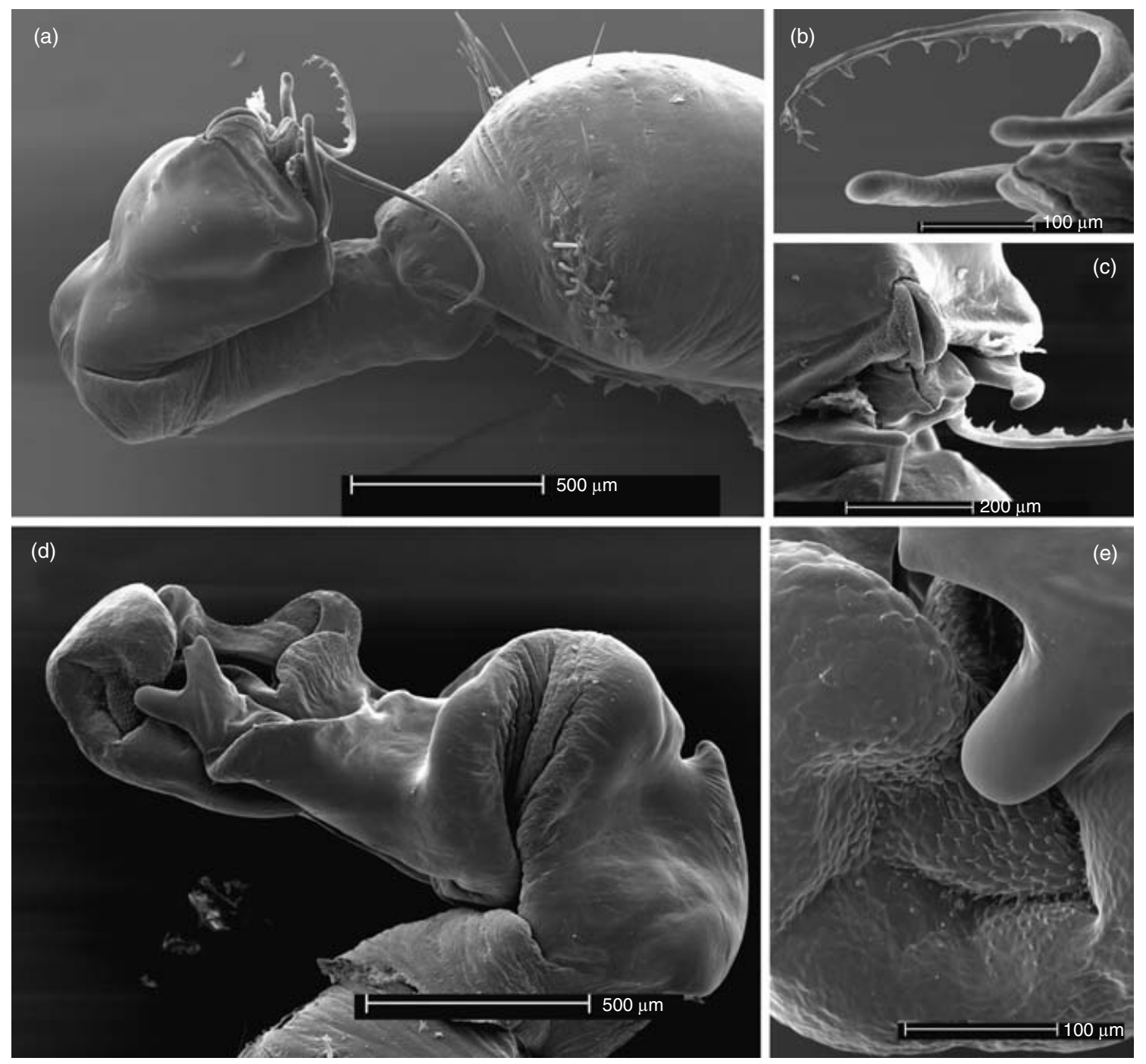

Fig. 4. Anisopteran penis: (a) lateral view of Libellula saturata penis; note the two thin flagella (detail in b) typical of some Libellulidae; (c) detail of the head of the L. saturata penis; (d) lateral view of Libellula depressa penis without flagella; (e) detail of the microspination in the penis head of $L$. depressa.

The anisopteran SSOs are enormously variable in shape and volumetric capacity. Two extremes can be distinguished with intermediate representatives (Siva-Jothy, 1987a,b): (1) species with small sperm stores and long and narrow spermathecae; (2) species with large and confluent spermathecae whose storage capacity is also large.

\section{MECHANISMS USED TO AVOID SPERM COMPETITION}

Frequently, studies of sperm competition lack a firm understanding of the genital copulatory mechanisms (Simmons \& Siva-Jothy, 1998). This information is essential to explain whether female, male and/or random processes are responsible for the observed patterns of sperm use (fertilization success) (Eberhard, 1996; Simmons \& Siva-Jothy, 1998; Simmons, 2001). In odonates, the way reproductive organs are positioned and the nature of copulatory mechanisms make them relatively easy to study. The investigation of copulatory mechanisms has been approached by using one or a combination of the following methods: (1) comparing sperm volumes and/or sperm number stored in the SSOs and male seminal vesicle before, during and after copulation (e.g. Waage, 1979); (2) directly observing the internal copulatory processes carried out by the couple (e.g. Miller, 1987a); (3) interrupting couples during copulation to observe the fitting of the still-engaged genitalia (e.g. Lindeboom, 1998); (4) comparing the morphology of male and female genitalia to determine correspondence between structures (e.g. Michiels, 1989); (5) observing the abdominal movements carried out by the couple during copulation (e.g. Thompson, 1990).

Possibly because of practical reasons, spermdisplacement mechanisms are better understood in Zygoptera than in Anisoptera. 

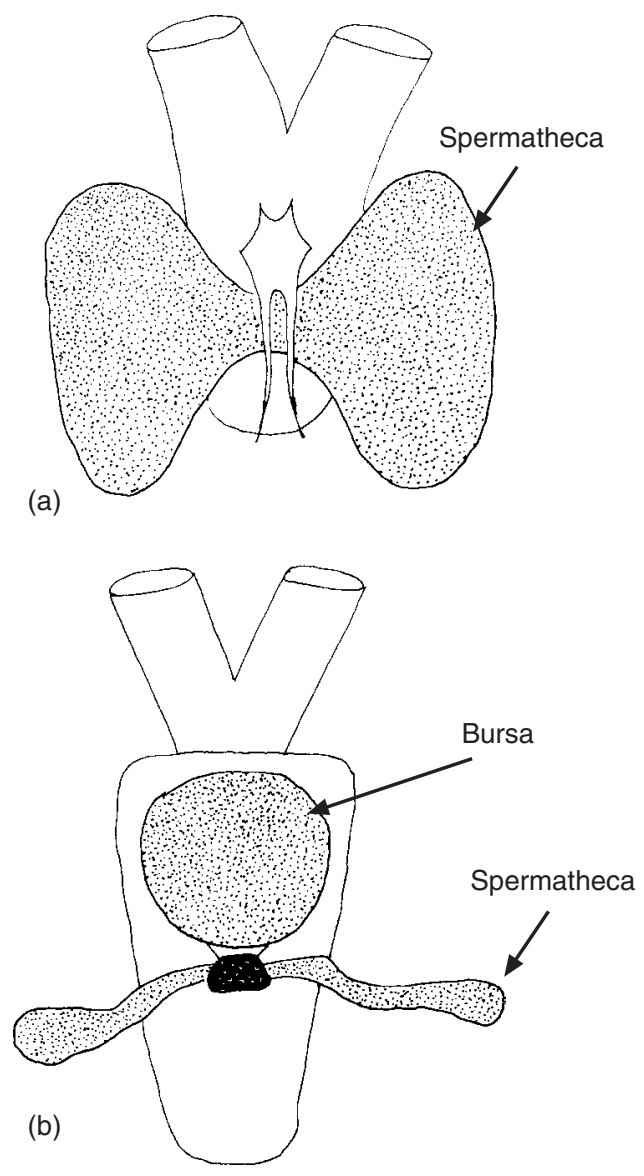

Fig. 5. Dorsal views of anisopteran female genitalia showing the sperm storage organs (redrawn from Miller, 1991). (a) Crocothemys erythraea; (b) Sympetrum striolatum.

\section{Sperm removal}

Since first described by Waage (1979) in Calopteryx maculata, this mechanism has been repeatedly demonstrated in the Calopterygidae (Siva-Jothy \& Tsubaki, 1989; SivaJothy \& Hooper, 1995; Lindeboom, 1998; CórdobaAguilar, 1999b) and other families of Zygoptera (Miller \& Miller, 1981; Waage, 1982a, 1984, 1986a; Miller, 1987b; Cordero \& Miller, 1992; Naraoka, 1994; Andrés \& Cordero Rivera, 2000). Although there is no direct evidence for this in anisopterans, its presence seems likely (Miller, 1984; Waage, 1986a; Siva-Jothy, 1988; Miller, 1990). Sperm removal is an efficient way for establishing a high fertilization success because the stored sperm is withdrawn from the female's SSOs.

In Zygoptera, the penis head and, if present, the associated penis head appendages are inserted in the SSO during copulation. The upper area of the penis head and the associated appendages are extended within the SSO and mechanically trap the sperm masses (see Fig. 2e). These masses are then moved to the outside by the in-and-out movements provided by the male abdominal segments and penis-associated musculature. Usually, both the penis head and its appendages are endowed with pointing spines that may facilitate sperm trapping and removal (Waage, 1979; Miller, 1987b; Cordero \& Miller, 1992).

Genital structures in Anisoptera such as the lateral, apical and inner lobes, the medial process, the flagella and the cornua may carry out the removal of sperm. These structures also have a series of spines on their distal surface (see Fig. 4b) which might be used during sperm trapping and retiring (Miller, 1991). As in Zygoptera, scooping out of sperm may be assisted by the rapid abdominal movements performed by the male during copulation (Miller, 1990, 1991). Females of such species may have large and thin spermathecae that male structures, such as the flagella, can enter (Michiels, 1989). In some other species with large SSOs, the male genitalia, such as the medial lobe, penetrate and displace a very small portion of the stored ejaculate, usually that located next to the bursa entry and close to the fertilization site (Siva-Jothy, 1988).

\section{Sperm repositioning}

Females of some species are able to store as many as 45 times the size of a male's ejaculate (e.g. Crocothemys erythraea; Siva-Jothy, 1988). The mechanism of sperm displacement in some of these species consists of pushing the stored sperm to places far from the fertilization site. The repositioned sperm are usually packed at the rear of spermathecae or distal areas of the bursa. In using this mechanism, males achieve a last in-first out advantage during fertilization (Michiels \& Dhondt, 1988).

In Zygoptera, sperm repositioning has been documented in Lestes vigilax (Waage, 1982b). It appears that the penis head carries out the compaction of rival sperm masses to those places far from the fertilization site. Unlike calopterygids or ischnurans, the penis head of this species has a ram-like form and has no distal appendages or spines on its surface, which suggests a poor sperm removal ability. Nevertheless this cannot be a generalization because males of Lestes barbarus, $L$. virens and $L$. viridis remove (completely in most cases) rivals' sperm from the SSOs, even if they have no distal appendages and their genitalia are similar to those of L. vigilax (see Fig. 2b; E. Uhía \& A. Cordero Rivera, pers. obs.). The SSOs are reduced to a single bean-like bursa in all those species, except female $L$. viridis, which has two small, round spermathecae. As in anisopterans, female L. vigilax can store a greater volume of sperm than the male is able to transfer to her, but this is not the case in the other mentioned Lestes species, whose bursa is smaller and is filled by a single ejaculate (E. Uhía \& A. Cordero Rivera, pers. obs.).

In Anisoptera, it has been postulated that structures such as the medial process, the cornua and the inner lobes dislodge the rivals' sperm masses also by pushing (Michiels, 1989; Miller, 1991). Some of these structures, i.e. the medial lobes and inner lobes, are inflatable (Miller, 1991). It has been proposed that, during copulation and once inside the SSO, they may expand and push the stored sperm (Miller, 1991). A second way in which 
repositioning could take place is by pushing the stored sperm using the copulating male's sperm (Michiels, 1989). This may be the case for those thin and large spermathecae that male structures cannot penetrate in some libellulids (Miller, 1991). Through the regular abdominal copulatory movements, the male may ejaculate directly (or close to) to the spermathecal entry, displacing the stored sperm distally.

\section{Sperm displacement by stimulation of the female sensory system}

Based on a previous claim by Miller (1987b, 1990) in a coenagrionid and a libellulid, the details of the mechanism were recently elucidated in a calopterygid (Córdoba-Aguilar, 1999b, 2002a). This mechanism is based on the fertilization process during which females eject stored sperm when stimulated by the male genitalia. In Zygoptera, females are partially responsible for sperm movements during fertilization (the other way by which spermatozoa can move is by their own flagellar activity; Miller, 1987b). Before fertilization, the egg stimulates a series of vaginal, mechanoreceptive sensilla embedded on the pair of sclerotized plates that are located ventrally to the SSOs (Miller, 1987b; Córdoba-Aguilar, 2003a). These sensilla are in control of the contractile activity of the muscles that surround the SSOs (Córdoba-Aguilar, 1999a). When the egg stimulates the sensilla, the SSO muscles of the spermathecae are excited and promote sperm expulsion from this organ. During copulation, the aedeagus, which is aligned along the vaginal plates, mimics the movement of the egg and thereby stimulates the sensilla inducing spermathecal sperm ejection (Córdoba-Aguilar, 2003a). This mechanism although recently documented, may, however, be extended to other species. In fact, in Ceriagrion tenellum, for example, this mechanism was the most likely explanation for spermathecal sperm displacement (Andrés \& Cordero Rivera, 2000).

\section{Multiple insemination and sperm flushing}

Multiple insemination has been described in Coenagrion scitulum by Cordero et al. (1995), but may also occur in Megaloprepus coerulatus (Fincke, 1984a) and in Paraphlebia quinta (González-Soriano \& CórdobaAguilar, 2003). Males of C. scitulum seem to have a poor sperm-displacement ability, given that their distally attached horns are too large to enter the single spermatheca, and are spineless. Males inseminate on repeated occasions (up to five times per copulation). Possibly, by outnumbering the stored sperm, a male is able to gain a higher fertilization success (Cordero et al., 1995). This mechanism can be used together with that of sperm flushing as both may be functionally related (sperm flushing may in some cases occur only if multiple insemination also takes place). In relation to the sperm flushing mechanism, Michiels (1989) and Michiels \& Dhondt $(1988,1991)$ proposed that males of the anisopteran Sympetrum danae may use their own sperm to dilute rival stored sperm. The sperm mixture (self and other males' sperm) may then be mechanically removed by the cornua. This mechanism may explain why males of several species have much more sperm in their sperm vesicles than they transfer to the female (Miller, 1984).

\section{The occurrence of different mechanisms and problems in their study}

Males of different species may simultaneously use several mechanisms during the same copulatory event. For example, in C. haemorrhoidalis asturica, males remove bursal sperm and stimulate females to induce spermathecal sperm ejection at the same time (CórdobaAguilar, 1999b). The same abdominal movements that promote bursal sperm displacement by the penis head, also help the aedeagus to stimulate the vaginal plate sensilla and displace spermathecal sperm. Similar processes may occur in other species but have not been documented in detail. Unfortunately, given the widespread ability of sperm displacement, sometimes circumstantial evidence is used to deduce sperm displacement patterns in this order. For example, the sole occurrence of abdominal movements has been used to infer sperm displacement (e.g. Ubukata, 1984; Thompson, 1990). Such assumption is not justified on the simple basis that males of species whose females mate only once in their lives also carry out pumping, sperm-displacement-like abdominal movements during copulation (e.g. Ischnura verticalis, Fincke, 1987). In these cases, the abdominal movements are clearly not intended to displace sperm since there is no sperm to displace (although, of course, the possibility remains that a phylogenetic constraint has left this behaviour in this species).

On some occasions close morphological correspondence between male and female genitalia has been used as an indication of male sperm-displacement ability (Waage, 1986a; Adams \& Herman, 1991; Robinson \& Novak, 1997). This is not true in all cases. In Ischnura, for instance, there is a close correspondence in the morphology of each of the two distal appendages of the penis head with that of the bursa and spermathecae, respectively (Waage, 1986a; Miller, 1987b). Indeed, in I. graellsii, one of the appendages enters the spermatheca while the other enters the bursa (Cordero \& Miller, 1992). But this, nevertheless, does not apply to I. elegans (Miller, 1987b). Cases similar to I. elegans have been found in other species (e.g. Celithemis elisa, Waage, 1986a; Mnais pruinosa pruinosa, Siva-Jothy \& Tsubaki, 1989). In different Calopteryx species, male and female genitalia are almost identical, but some are able to remove sperm from the bursa and the spermatheca (Waage, 1979) and others only from the bursa (Siva-Jothy \& Hooper, 1995; Córdoba-Aguilar, 2002a). 
Copulation duration has also been used for predicting copulatory mechanisms. In different studies, it was proposed that sperm 'removers' and sperm 'repositioners' could be separated on the basis of copulation duration: copulation in 'removers' would take longer than 'repositioners' (Miller, 1981; Siva-Jothy, 1984; Waage, 1984). It was assumed that the act of sperm removal would take longer since it is a more complex and coordinated activity. This expectation was, however, rejected by Waage (1986a) from studies in two 'remover' dragonfly species with extreme copulation durations. Furthermore, in C. tenellum males remove all the sperm from the bursa in just $10 \mathrm{~min}$, but copulation takes 1-3 h (Andrés \& Cordero Rivera, 2000).

Another set of assumptions used to infer sperm displacement is the presence and/or form of certain morphological male genital structures (e.g. Adams \& Herman, 1991; Robinson \& Novak, 1997; Artiss, 2001). This is the case, for example, of penis horns and pointing spines which in different species are used during sperm manipulation (e.g. C. maculata, Waage, 1979). Studies with Ischnura show that this is a simplistic assumption: I. elegans is a species with penis horns but no spermathecal sperm removal (Miller, 1987b), and I. graellsii is a species with horns and spermathecal sperm removal (Cordero \& Miller, 1992).

The corollary of this is that copulatory mechanisms are difficult to infer. The best way to study them is to use different approaches, preferably the interruption of in-copula pairs and observation of the genital disposition. This should be accompanied by the measurement of sperm volume changes before, during and after copulation.

\section{ESTIMATES OF ODONATE SPERM PRECEDENCE AND MALE AND FEMALE INFLUENCES}

Sperm precedence estimates in odonates have been calculated using standard paternity methods (radiation or molecular techniques), genetic markers or they have been extrapolated from data of the volume of sperm displaced during copulation. We have arranged these estimates in Table 1 .

Interspecific sperm-displacement patterns are extremely variable, from species such as Calopteryx maculata in which $80-100 \%$ of sperm is removed (leaving little space for the female's use of previous mates' sperm; Waage, 1979) to species such as Sympetrum danae that remove $41-80 \%$ of sperm (Michiels \& Dhondt, 1988). Measurement of the sperm displaced has been taken mostly in species using a sperm removal mechanism. It would be interesting to investigate if the use of a certain mechanism makes displacement and fertilization more efficient. Variation in sperm displacement must be interpreted with care unless it is translated into studies of paternity. Studies of paternity (the proportion of eggs fertilized by the last copulating male) have been carried out in 11 species. They also show considerable interspecific variation (mean \pm SD): from $1 \pm 0$ in Anax parthenope (Hadrys et al., 1993) to $0.79 \pm 0.2$ in
I. elegans (Miller, 1987b; Cooper, Miller \& Holland, 1996).

In several species, however, last-male sperm precedence tends to decrease with time as a consequence of the mixing of sperm caused by the inability of males to displace all stored sperm (e.g. Siva-Jothy \& Tsubaki, 1989; Cordero \& Miller, 1992; Sawada, 1998). If females spend some time without copulating again, the sperm from the last male gets mixed with those that are already stored. Such sperm mixing has been observed when females were given time to lay more than a single clutch of eggs. For example, in Erythemis simplicicollis, last-male precedence fell from $99.5 \%$ to $64 \%$ after 2 days (McVey \& Smittle, 1984). Unfortunately, this extra time was not given to all studied species so that sperm mixing was not verified, an uncertainty that should be resolved in future studies. The benefits, if any, of sperm mixing for females are unclear. If females promote sperm mixing, under particular conditions they should delay sperm use until sperm is mixed. Interestingly, some observations of female behaviour suggest that females overtly use mixed sperm. Males of Calopteryx xanthostoma do not have access to the sperm stored in the spermathecae so that the sperm received from different males tends to accumulate in this organ (Siva-Jothy \& Hooper, 1996). Interestingly, females use the mixture of spermathecal sperm under particular circumstances. The benefit of using mixed sperm remains obscure, but one possibility is that females use the spermathecae cryptically to allocate the sperm of high-quality males to this organ (for a more elaborated argument of this see below). Such a possibility applies not only to those species whose spermathecal access is not available, but to any species with incomplete sperm displacement. It would be illuminating to know whether sperm mixing is promoted by the female and, if this is the case, what females gain from doing so.

It is desirable that sperm precedence studies should be accompanied by an investigation of the underlying copulatory mechanisms to understand male and female influences (Simmons \& Siva-Jothy, 1998). Regarding those species whose males displace sperm by removal or sensory stimulation, three patterns of sperm displacement have been found: (1) males have total access to the bursa and the spermathecae; (2) males have access to the bursa but not to the spermathecae; (3) males have access to the bursa and partial access to the spermatheca. Only in the first pattern do males displace all sperm and therefore obtain $100 \%$ sperm precedence. In the other two patterns, fertilization success would depend on whether or not each sex has some control of paternity (a random process). If variation is caused by males, two factors can be outlined as below.

(1) Male variation in the genital morphology used for displacing sperm. One case supporting this is that of Calopteryx haemorrhoidalis asturica in which males stimulate the female sensory system to displace spermathecal sperm (Córdoba-Aguilar, 1999b). Varying degrees of sperm displacement are related to the width of the aedeagus that provides the stimulus: the wider this structure, the more sperm it is able to displace. 
Table 1. Summary of sperm competition mechanisms, the methods used for their investigation, and patterns of sperm precedence in Odonata

\begin{tabular}{|c|c|c|c|c|}
\hline Species & Methods used & Sperm competition mechanism & $\mathrm{P}_{2}$ value & Reference \\
\hline \multicolumn{5}{|l|}{ Calopterygidae } \\
\hline Calopteryx maculata & $\begin{array}{l}\text { Morphological study } \\
\text { Sperm volume measurement }\end{array}$ & Removal: $88-100 \%$ & - & Waage, 1979 \\
\hline $\begin{array}{l}\text { Calopteryx splendens } \\
\text { xanthostoma }\end{array}$ & RAPD & $\begin{array}{l}\text { Removal (bursa only): } 49 \% \\
\text { (calculated from figure 1) }\end{array}$ & 0.98 & $\begin{array}{l}\text { Siva-Jothy, Gibbons \& } \\
\quad \text { Pain, } 1995 \\
\text { Hooper \& Siva-Jothy, } 1996\end{array}$ \\
\hline Calopteryx dimidiata & $\begin{array}{l}\text { Morphological study } \\
\text { Sperm volume measurement }\end{array}$ & Removal 98\% & - & Waage, 1988 \\
\hline $\begin{array}{l}\text { Calopteryx haemorrhoidalis } \\
\text { asturica }\end{array}$ & $\begin{array}{l}\text { Morphological study } \\
\text { Sperm volume measurement }\end{array}$ & $\begin{array}{l}\text { Removal (bursa only): } 60-100 \% \\
\text { It is suggested sensilla stimulation } \\
\text { to elicit spermathecal sperm } \\
\text { ejection }(0-100 \%)\end{array}$ & - & Córdoba-Aguilar, 1999a \\
\hline $\begin{array}{l}\text { Calopteryx haemorrrhoidalis } \\
\text { haemorrhoidalis }\end{array}$ & $\begin{array}{l}\text { Morphological study } \\
\text { Sperm volume measurement }\end{array}$ & $\begin{array}{l}\text { Removal: bursa: } 100 \% \text {, spermathecae: } \\
\text { usually only one spermathecae } \\
\text { is emptied }\end{array}$ & - & $\begin{array}{l}\text { A. Cordero, J. A. Andrés, } \\
\text { S. Santolamazza \& C. Utzeri, } \\
\text { pers. obs. }\end{array}$ \\
\hline Mnais pruinosa pruinosa & $\begin{array}{l}\text { Morphological study } \\
\text { Sperm volume measurement } \\
\text { Sterile male technique }\end{array}$ & Removal (bursa only): up to $100 \%$ & $\begin{array}{l}1 \text { (short-term) } \\
0.5 \text { (after } 6 \text { days) }\end{array}$ & Siva-Jothy \& Tsubaki, 1989 \\
\hline \multicolumn{5}{|l|}{ Coenagrionidae } \\
\hline $\begin{array}{l}\text { Argia moesta } \\
\text { Argia sedula }\end{array}$ & $\begin{array}{l}\text { Morphological study } \\
\text { Sperm volume measurement }\end{array}$ & $\begin{array}{l}\text { A. moesta: removal } 85 \% \text { ( } 93 \% \text { bursa }) \\
\text { A. sedula: removal } 66 \%(71 \% \text { bursa }) \\
\text { Males of both species might empty } \\
\text { the spermatheca }\end{array}$ & - & Waage, $1986 b$ \\
\hline Argia fumipennis violacea & $\begin{array}{l}\text { Morphological study } \\
\text { Sperm volume measurement }\end{array}$ & $\begin{array}{l}\text { Virtually all sperm removed from } \\
\text { the bursa }\end{array}$ & - & Waage, 1984 \\
\hline Ischnura ramburii & $\begin{array}{l}\text { Morphological study } \\
\text { Sperm volume measurement }\end{array}$ & $\begin{array}{l}\text { Removal: } 52 \% \text { ( } 82 \% \text { bursa) } \\
\text { Males might empty the spermatheca }\end{array}$ & - & Waage, $1986 b$ \\
\hline Ischnura verticalis & $\begin{array}{l}\text { Morphological study } \\
\text { Sperm volume measurement }\end{array}$ & $\begin{array}{l}\text { No sperm removal: females } \\
\text { monogamous }\end{array}$ & - & Fincke, 1987 \\
\hline Ischnura elegans & $\begin{array}{l}\text { Morphological study } \\
\text { Sperm volume measurement } \\
\text { Microsatellites }\end{array}$ & $\begin{array}{l}\text { Removal (bursa only): } 100 \% \\
\quad \text { ( } 26 \% \text { of total) }\end{array}$ & $\begin{array}{l}0.79 \pm 0.2 \\
\text { range: } 0.44-1\end{array}$ & $\begin{array}{l}\text { Miller, } 1987 b \\
\text { Cooper et al., } 1996\end{array}$ \\
\hline Ischnura graellsii & $\begin{array}{l}\text { Morphological study } \\
\text { Sperm volume measurement } \\
\text { Genetic markers }\end{array}$ & $\begin{array}{l}\text { Removal: } 67 \% \text { bursa } \\
\text { Removal: } 100 \% \text { spermatheca }\end{array}$ & $\begin{array}{l}0.987 \pm 0.012 \\
\text { range from } 2 \text { nd } \\
\text { clutch: } 0.44-1\end{array}$ & Cordero \& Miller, 1992 \\
\hline Ischnura asiatica & $\begin{array}{l}\text { Morphological study } \\
\text { Sperm volume measurement }\end{array}$ & $\begin{array}{l}\text { Removal: } 71 \% \text { bursa } \\
\text { Removal: } 61 \% \text { spermatheca }\end{array}$ & - & Naraoka, 1994 \\
\hline Ischnura senegalensis & $\begin{array}{l}\text { Morphological study } \\
\text { Sperm volume measurement } \\
\text { Sterile male technique }\end{array}$ & $\begin{array}{l}\text { Removal: } 100 \% \text { bursa }(50 \% \text { total) } \\
\text { Removal of spermatheca? } \\
\text { Copulation duration much longer } \\
\text { than necessary to sperm removal }\end{array}$ & $\begin{array}{l}0.986 \pm 0.9 \\
\mathrm{P}_{2} \text { diminishes with time } \\
\quad(0.5 \text { after } 6 \text { days })\end{array}$ & $\begin{array}{l}\text { Sawada, } 1995 \\
\text { Sawada, } 1998\end{array}$ \\
\hline Coenagrion scitulum & $\begin{array}{l}\text { Morphological study } \\
\text { Sperm volume measurement }\end{array}$ & $\begin{array}{l}\text { Limited sperm removal ability } \\
\text { Abundant insemination }\end{array}$ & - & $\begin{array}{l}\text { Utzeri \& Sorce, } 1988 \\
\text { Cordero et al., } 1995\end{array}$ \\
\hline Enallagma hageni & $\begin{array}{l}\text { Morphological study } \\
\text { Sperm volume measurement } \\
\text { Sterile male technique }\end{array}$ & $\begin{array}{l}\text { Removal: } 83 \% \text { bursa } \\
\text { Removal spermatheca? }\end{array}$ & $0.795-0.95$ & Fincke, $1984 b$ \\
\hline Enallagma cyathigerum & $\begin{array}{l}\text { Morphological study } \\
\text { Sperm volume measurement }\end{array}$ & $\begin{array}{l}\text { Removal: } 100 \% \text { bursa in } 12 / 18 \\
\text { females at the end of stage I; } \\
50 \% \text { in } 6 / 18 \text { ) } \\
\text { It is suggested no spermathecal removal }\end{array}$ & - & $\begin{array}{l}\text { Miller \& Miller, } 1981 \\
\text { Perry \& Miller, } 1991\end{array}$ \\
\hline Cercion sieboldii & $\begin{array}{l}\text { Morphological study } \\
\text { Sperm volume measurement }\end{array}$ & Removal 70\% & - & Naraoka, 1986 \\
\hline Ceriagrion tenellum & $\begin{array}{l}\text { Morphological study } \\
\text { Sperm volume measurement } \\
\text { Sterile male technique }\end{array}$ & $\begin{array}{l}\text { Removal: } 100 \% \text { bursa in only } 5-10 \mathrm{~min} \\
\text { It is suggested sensilla stimulation to } \\
\text { elicit } \\
\text { Spermathecal sperm ejection } \\
\text { Copulation duration much longer } \\
\text { than necessary to sperm removal }\end{array}$ & $\begin{array}{l}0.98 \pm 0.06 \\
\text { Great variability in } \mathrm{P}_{2} \\
\text { that does not depend } \\
\text { on copulation duration }\end{array}$ & Andrés \& Cordero Rivera, 2000 \\
\hline \multicolumn{5}{|l|}{ Platycnemididae } \\
\hline Platycnemis pennipes & Morphological study & $\begin{array}{l}\text { Sperm removal ability unclear } \\
\text { from penis morphology }\end{array}$ & - & Kuhn, 1989 \\
\hline Platycnemis acutipennis & Morphological study & $\begin{array}{l}\text { P. acutipennis: removal: } 95 \% \text { bursa, } \\
39 \% \text { spermatheca }\end{array}$ & & $\begin{array}{l}\text { E. Uhía \& A. Cordero Rivera, } \\
\text { pers. obs. }\end{array}$ \\
\hline Platycnemis latipes & Sperm volume measurement & $\begin{array}{l}\text { P. latipes: removal: } 100 \% \text { bursa, } \\
25 \% \text { spermatheca }\end{array}$ & & \\
\hline
\end{tabular}


Table 1. Continued

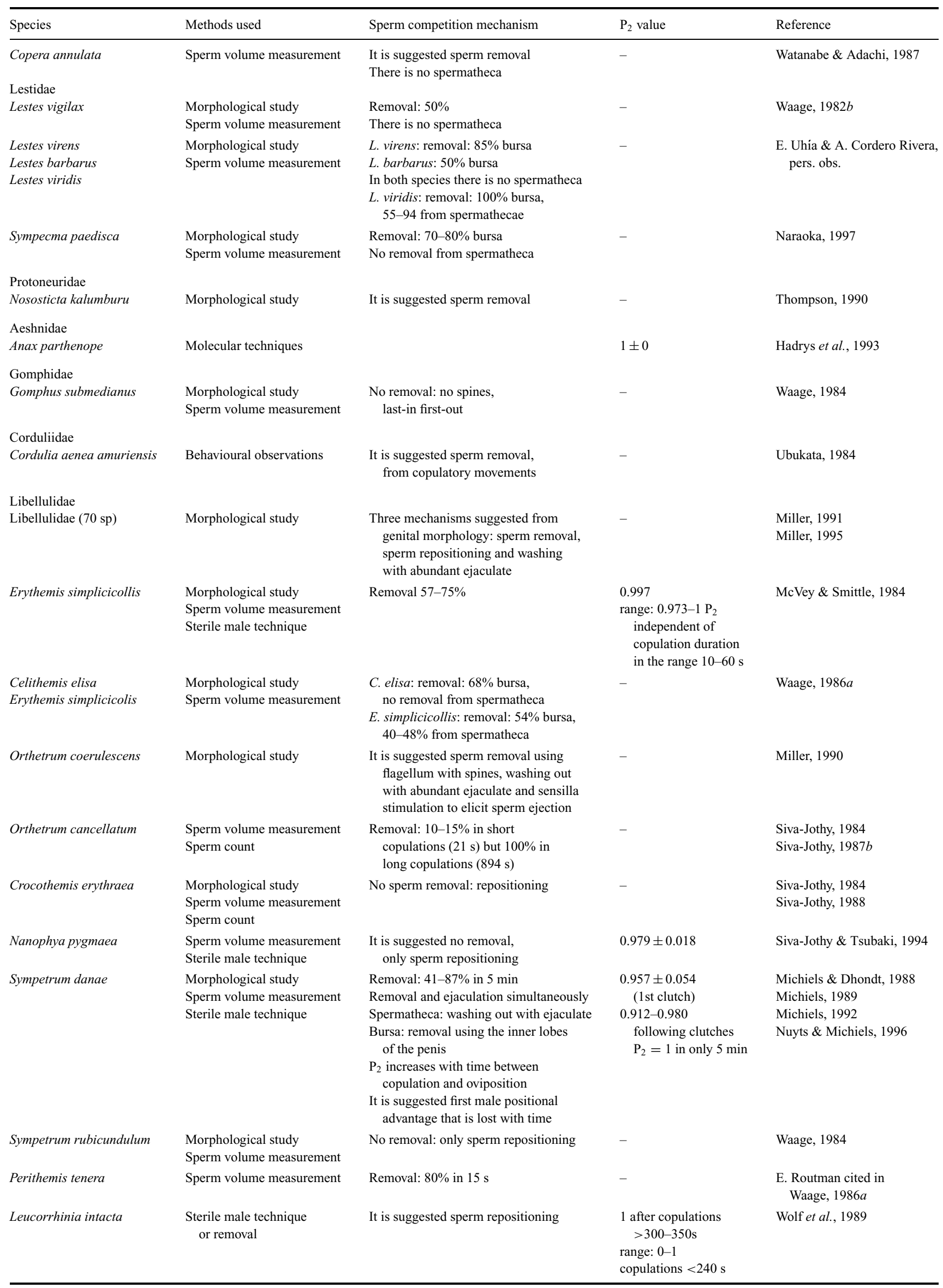


These results held even when other potential variables were examined (Córdoba-Aguilar, 2001). Since there is considerable variation in aedeagal width among males, variation in sperm displacement is also high. Another case may occur in Ischnura graellsii in which some males were consistently more successful in fertilization success, even if they were the first to mate with the female (since their sperm may have been displaced; Cordero \& Miller, 1992). Since males show considerable variation in the length of the penis head appendages used for removal, variation in fertilization success might be caused by inter-individual variation in genital morphology.

(2) Copulation duration, which is largely controlled by males (Miller \& Miller, 1981; Miller, 1987b), may vary and be inversely related to sperm-displacement rate. Different supporting evidence has been found for this hypothesis. For example, males of Mnais pruinosa pruinosa differ in their copulation duration: males that copulate for longer were able to displace larger sperm volumes (Siva-Jothy \& Tsubaki, 1989). Similar results have been found in some other species (e.g. Orthetrum cancellatum, Siva-Jothy, 1984, 1987c). Nevertheless, in other cases sperm removal seems quick and therefore copulation duration is not related to sperm-displacement rate (Andrés \& Cordero Rivera, 2000) but to copulationpreventing tactics such as mate guarding (Cordero, 1990).

One proximate male factor that may explain spermuse patterns in species with repositioning, multiple inseminations and/or sperm flushing mechanisms is variation in copulation duration. Longer copulations may provide more time to 'reposition', 'flush' or transfer more sperm. In fact, extra time to inseminate more sperm occurs in Coenagrion scitulum (Cordero et al., 1995).

In these sperm displacement mechanisms, female factors that can alternatively explain patterns of sperm use or displacement have been discussed (Miller, 1987b, 1990, 1991; Cordero \& Miller, 1992) but never investigated. The main problem presented by this lack of information is that it is difficult to assert which female processes can be determining sperm use. Theoretically, and as occurs in other insects (Eberhard, 1996; Simmons \& Siva-Jothy, 1998; Simmons, 2001), females have a great potential to favour the sperm of some males over others using their reproductive anatomy and physiology. There is at least one example where variation in paternity is apparently under female control. In Ceriagrion tenellum male fertilization success was greater after long rather than after short copulations, even if the amount of sperm displaced (from the bursa only) was the same in both types of matings (Andrés \& Cordero Rivera, 2000). A broad and hypothetical picture of female control mechanisms can be outlined.

(1) Movements by SSOs to avoid sperm displacement. The SSOs are richly-innervated structures (CórdobaAguilar, in press) with distinctly-orientated muscular arrangements surrounding them (Siva-Jothy, 1987a; Hooper, 1994; Andrew \& Tembhare, 1996; CórdobaAguilar, 2003a). Different orientations of the SSOs in distinct individuals have been found in females whose copulations have been interrupted (Cordero \& Miller,
1992). SSO movements have been also observed in dissected, in-vivo females (Miller, 1987b; CórdobaAguilar, 2003a). In these cases, SSO movements may have made sperm removal more difficult or impossible.

(2) Re-distribution of stored sperm before fertilization (Miller, 1989; Miller \& Miller, 1989). The SSO muscles may be used to manipulate the allocation of sperm within the SSO. This may help the female to give priority to some sperm over others

(3) Control over certain sperm-storing sites during fertilization. As indicated by observations with in-vivo females (Córdoba-Aguilar, 2003a), muscles may provide independent contractile activity for each spermatheca. This ability may give them the opportunity to use a specific storing site over others during fertilization. In fact, $C$. xanthostoma females are able to use bursal and spermathecal sperm differentially (Siva-Jothy \& Hooper, 1995, 1996).

(4) Sperm ejection during and after copulation. Females may eject sperm during copulatory breaks (Cordero et al., 1995; González-Soriano \& Córdoba-Aguilar, 2003) and soon after copulation (Lindeboom, 1998; GonzálezSoriano \& Córdoba-Aguilar, 2003). Although this ability as a mean of paternity control has been rejected (Lindeboom, 1998), it seems to be a common phenomenon in odonates (Cordero Rivera, 2002) and deserves further investigation.

Finally, variation in sperm-precedence patterns may be due to a random process. The sperm mixing may be simply explained as the normal outcome when two fluids are put together in a closed structure and left for some time. Why sperm precedence takes less or more time to decrease would depend on how long it takes the sperm to mix.

\section{THE EVOLUTION OF ODONATE COPULATORY MECHANISMS}

Copulatory mechanisms in Odonata and patterns of sperm use can be understood only on the basis of the evolutionary interaction between the sexes for the control of stored sperm. Given that females store sperm, it pays males to evolve traits to induce them to use their own sperm and not other males' stored sperm. Therefore, the evolution of male strategies to displace sperm would be a consequence of the selective pressure generated by the female ability to store sperm and mate multiply. We suggest that females and males have been co-evolving at the level of copulatory mechanisms. The set of copulatory mechanisms, their different morphological and functional genital adaptations would be like different views of a mosaic of evolutionary outcomes arrived at by different species. On the one hand, females have been evolving sperm-storage structures with particular morphologies whilst males, on the other hand, have been evolving genital morphologies to displace the stored sperm. As suggested by Waage (1986a) for Zygoptera, phylogenetically, this is the most likely and parsimonious scenario. Take, for example, members of the 
genus Lestes whose origin is considered to be ancestral in zygopteran phylogeny. The male and female genital morphology is relatively simple (Figs $2 \& 3$ ). Females bear an undifferentiated sperm-storage organ whose bursal and spermathecal sites are not distinguishable from each other, but in some species, like Lestes viridis, females have evolved a true spermatheca (E. Uhía \& A. A. Cordero Rivera, pers. obs.). Male ability to manipulate rival sperm may also be, relatively speaking, simple. In these species, males use a repositioning strategy (Waage, 1982b). On the other hand, in Calopteryx species, whose origin is more recent, both sexes seem to have more specialized genitalia. Males have penis lateral appendages covered with spines while females have a well differentiated bursa and paired spermathecae. Similar evolutionary transitions may be interpreted in the Anisoptera. A broad comparison may be made between the Aeshnidae, an 'old' family, against one of those families whose origin is more recent, the Libellulidae (Trueman, 2001). In Anax junius, for example, the distal segment of male genitalia has a spherical morphology whose function is possibly associated with sperm repositioning (Waage, 1986a). The bursa is a spherical structure and ends in a paired spermatheca. On the other hand, the libellulid genitalia show a striking complexity (Miller, 1991; Artiss, 2001). Males have varied structures (e.g. flagella, cornua, among others). Female genitalia are similarly variable in morphology and in volumetric capacity (especially the spermathecae). Copulatory mechanisms, although more intensively studied in this than in other families, are diverse too and may include sperm removal, sperm reposition, sperm flushing and sensory stimulation (Miller, 1991).

Given these differences in odonate genital morphology, one may try to construct a general, hypothetical series of evolutionary events to try to explain current genital diversity. The first structure that may have appeared is a Lestes-like bursa copulatrix whose primary function was to store sperm. The benefits to females of the evolution of sperm-storing abilities are unknown (as is so for most insects; Alexander, Marshall \& Cooley, 1997; see below for a more elaborated discussion) but, whatever the benefit, the storing ability may have been selective enough on males to favour the appearance of sperm-displacement traits. The less specialized of the sperm-displacement abilities could have been a structure that was only able to reposition sperm (a structure with no lateral appendages or spination). Assuming that males were able to access bursal sperm, this may have been followed by the evolution of small, not-clearly differentiated spermathecae to keep sperm unreachable. Further evolution of male displacement abilities may have come with a variety of 'solutions' such as sperm removal, sperm flushing and multiple insemination (through the presence of lateral appendages, cornua, flagella, pointing spines, among other structures). These abilities are now widespread in the order and in some species males may use more than one (e.g. Calopteryx haemorrhoidalis asturica, Córdoba-Aguilar, 1999b). Perhaps the most recent ability is sperm removal, as judged by its presence in those species whose origin is more recent (e.g. species of Calopteryx and Libellula). Females may have been evolving more solutions to keep the sperm unreachable. Some possibilities are a size reduction of the spermathecal ducts to impede male penetration (Córdoba-Aguilar, $1999 b$ ), spermathecal ducts that are longer than male genital structures such as the cornua or the flagella (Miller, 1991; A. Cordero Rivera, pers. obs.), among other possibilities that are not apparent from the available information, but that are also feasible such as muscular movements during copulation (Córdoba-Aguilar, 2003a) that re-distribute sperm or impede sperm displacement and sperm ejection.

Some cases that may be used as supporting evidence for this co-evolutionary scenario are worth mentioning. Species of Calopterygidae may serve as one example. In Calopteryx species, males have evolved two mechanisms to displace stored sperm: sperm removal and sensory stimulation. In all species males displace bursal sperm; there are, however, interspecific differences in the ability to displace spermathecal sperm. Spermathecal sperm removal takes place only if the male lateral appendages on the penis head are narrow enough to enter the spermathecal ducts (Córdoba-Aguilar, 1999a, 2002a, 2003b). Males of one species, C. haemorrhoidalis asturica, despite not having access to the spermathecal ducts because of the size difference in penis appendages and spermathecal ducts, have evolved the ability to stimulate the sensory system of females (a set of vaginal sensilla) (CórdobaAguilar, 1999b, 2002a). Recent results suggest that the most probable scenario for the evolution of this male ability is that males were first able to have physical access to the spermathecae; the access was afterwards impeded by the dimensional spermathecal duct reduction which was then followed by the sensory stimulation ability (Córdoba-Aguilar, 2002a). Interestingly, C. h. asturica females show the lowest sensillum numbers in relation to other calopterygids, a fact that has been interpreted as means to make sperm displacement more difficult to males (Córdoba-Aguilar, 2003b). It would be interesting to investigate whether changes in genital morphology (narrow or wide spermathecal ducts, lower sensillum number, etc.) are correlated with changes in copulatory mechanisms and spermathecal sperm accessibility in Calopteryx species. Such a study can now be carried out because there is a phylogeny available for the Calopteryx genus (Misof, Anderson \& Hadrys, 2000).

Another case to be pointed out is that of Ischnura. Work by Robinson \& Novak (1997) has shown that males in different species have a genital morphology which correlates with female mating patterns. In this genus, males have two penis lateral appendages provided with pointing spines which remove the sperm present in the spermathecae (e.g. Waage, 1986a; Cordero \& Miller, 1992; Naraoka, 1994). However, there are a few species that lack the penis spination and have their lateral appendages reduced. Females of some of these species mate only once in their lives which would explain why their conspecific males lack the structures needed for spermathecal sperm displacement. This example shows 
how female mating frequency and male displacement ability may be linked.

Although copulatory mechanisms in Odonata are relatively well known compared to those of other insects, much of the current knowledge is limited to a few taxa. In Zygoptera, for example, copulatory mechanisms have been studied in only three (Calopterygidae, Coenagrionidae and Lestidae) out of 18 families. In Anisoptera, the situation is similar, since only one family (Libellulidae) out of 10 has been studied (Table 1). With such limited information, and although the patterns with the studied species depict a co-evolutionary scenario, it is still difficult to develop generalizations from so few species. Information on copulatory mechanisms in littlestudied families will be highly valuable.

\section{What drives the co-evolution?}

One central issue in these arguments is what females gain in the genital, co-evolutionary game. We know that males gain in paternity (the more sperm they displace, the higher is their fertilization success; Simmons, 2001) but the benefits for females are not so evident. Studies addressing this in odonates are badly needed. Benefits for females of evolving structures such as the bursa and spermathecae are somehow related to the benefits of mating multiply. A general framework for the evolution of multiple mating has been thoroughly discussed by Fincke (1997). However, the benefits of storing and retaining sperm during sperm displacement for females can be different to those for multiple mating outlined by Fincke, and may include the following: (1) direct benefits for the female: mate guarding, fertility insurance, increased fecundity and nutritional intake; (2) indirect benefits for the progeny: attractive genes, genetic diversity, viability genes and genetic complementarity. We will discuss the operation of each of these benefits.

The risk of sperm displacement provided the conditions for the evolution of certain male activities, and among these is male mate guarding (Simmons, 2001). Given that odonate females can be harassed by males during oviposition (e.g. Cordero, 1999; Cordero Rivera \& Andrés, 2002) which can take dramatic forms (such as serious injuries; e.g. Corbet, 1999), there is a considerable benefit of being guarded by their mates. In allowing sperm displacement by females with the consequent risk in paternity for males, females may have provided the conditions for mate guarding. This benefit, however, would have come after the evolution of the sperm displacement ability and, therefore, cannot explain the origin of the sperm storage ability (for a similar rationale see Fincke, 1997).

Female insects may derive the benefit of avoiding male infertility by mating multiply and retaining sperm (Tregenza \& Wedell, 2002). It may be that a single male is able to transfer enough sperm to fertilize all eggs. However, if there are enough males whose sperm are not fertile or incompatible, selection will operate to increase the number of matings. This possibility has not been examined in Odonata. One possibility is that sperm tend to become infertile with time and that is why females would have to mate again before oviposition. The scarce evidence in Odonata suggests that this may not be a problem. In at least some species of Ischnura, female fertility remains high during $>2$ weeks after a single mating (Grieve, 1937; Fincke, 1987; Cordero, 1990).

It has been shown in different insect species that females may acquire increased fecundity as a by-product of multiple mating and sperm storage ability (reviewed by Ridley, 1988; Arnqvist \& Nilsson, 2000). This may have different explanations but, in general, males may provide females with seminal substances that increase fertility, eggproduction rate and female life span (Arnqvist \& Nilsson, 2000). An analysis of seminal substances and their possible effects on female fitness has not been carried out for Odonata. Any result in this area will be illuminating.

Sperm may be used as an alternative source of food in butterflies and orthopterans (Thornhill \& Alcock, 1983; Simmons \& Siva-Jothy, 1998). In these insects, fecundity is heavily increased via the seminal products transferred during copulation. This possibility, however, has been discarded in Odonata (Fincke, 1997). Although histological studies suggest that the SSO tissues may not have such a function (Siva-Jothy, 1987a; Andrew \& Tembhare, 1996; Córdoba-Aguilar, 2003a), this hypothesis still has to be tested.

Benefits may be of a different kind. Females may gain in attractive offspring if they mate and store the sperm of attractive males (Keller \& Reeve, 1995) giving rise to Fisherian selection (Fisher, 1930). Although this may be difficult to test in odonates, it has been suggested as an explanation for certain male copulatory abilities such as causing females to eject stored sperm (CórdobaAguilar, 1999b; Andrés \& Cordero Rivera, 2000). In Ceriagrion tenellum, for example, the only way males have access to spermathecal sperm is by stimulating the female sensory system during copulation (Andrés \& Cordero Rivera, 2000). The inter-individual variation in spermathecal sperm displaced, along with the variation in fertilization success found in this species, suggests that males vary in their ability to stimulate females. It may be that females are choosing 'attractive' mates on the basis of a male's ability to induce her to eject spermathecal sperm.

Females may be retaining sperm from different males to increase the genetic diversity of their offspring (Williams, 1975; Brown, Crespi \& Choe, 1997). On theoretical grounds, this benefit is unlikely as diversity does not seem to increase with multiple mating (Williams, 1975; but see Yasui, 1998). A more likely possibility is that females may be storing sperm of high-quality males to obtain viability genes for their offspring instead of genetic diversity. New studies in the Calopterygidae suggest that this may be the case. In several species of this family, males have pigmented wings. Pigmentation gets fixed following some days after emergence (Córdoba-Aguilar, 1993; Hooper, Tsubaki \& Siva-Jothy, 1999; Kirkton \& Schultz, 2001) but 
shows considerable inter-individual variation (e.g. SivaJothy, 2000). Observational and experimental evidence (Siva-Jothy, 2000; Córdoba-Aguilar, 2002b) suggest that males show their wings during courtship to females (e.g. Córdoba-Aguilar, 2000; Siva-Jothy, 2000) and the distinct levels of pigmentation may differentially signal the male's ability to cope with an eugregarine intestinal parasite. Calopteryx females not only prefer males with more pigmentation (Siva-Jothy, 1999; Córdoba-Aguilar, 2002b) but those females that mate more often do so with highly pigmented males (Córdoba-Aguilar, Salamanca-Ocaña \& Lopezaraiza-Mikel, 2003). This evidence suggests that females may be mating multiply and with high-quality males to obtain genes that provide resistance to parasites for their offspring. One remaining issue to be investigated here is whether offspring inherit the same resistance to parasites.

Finally, females may mate multiply to attain genotypic complementarity (Tregenza \& Wedell, 2002) expressed at the level of male and female gamete interactions. Different sources of evidence suggest this may be the case in some animal species (Zeh \& Zeh, 2001). Its occurrence in odonates needs to be tested.

In summary, it is still premature to seek generalizations about the reasons that underlie multiple mating to explain the evolution of sperm-storage ability in Odonata. The hypothesis of females benefiting by obtaining viability genes as an explanation for female mating patterns is supported for some species of Calopterygidae. In Calopteryx species, the fact that males advertise their quality to females through pre-copulatory courtship (via wing pigmentation) may provide females with the opportunity to assess a male's parasite resistance. Interestingly, both courtship and male pigmentation occur together in different species (Fincke, 1997; Fincke, Waage \& Koenig, 1997; A. Córdoba-Aguilar, pers. obs.). However, the number of species with both characteristics is relatively scarce in Odonata. This means that the hypothesis of quality advertising during pre-copulatory courtship by males, at least in the way it occurs in Calopteryx, is restricted to a few taxa and therefore further generalizations cannot be made. In fact, in many other species whose males have pigmented wings (including other Calopterygidae, Johnson, 1961) males merely grab females when the latter arrive to oviposition sites. Females may offer some resistance after this. Such male behaviour would seem to make it difficult for females to assess male quality (based on wing pigmentation) but it may illustrate a counter response by males to a female control mechanism. One example of our inability to arrive at general explanations for female multiple mating patterns is the occurrence of monogamy in different Ischnura species whose females are successful in avoiding male copulatory attempts after having mated once (Fincke, 1987; Robinson \& Novak, 1997). In this case, monogamous patterns would contradict any benefit that sperm storage from multiple males might provide.

In conclusion, we are still far from understanding the adaptive significance of the sperm storage ability. Most observations are limited to a few species and even in these, our knowledge is sparse.

\section{ODONATES AS MODELS FOR TESTING SEXUAL SELECTION HYPOTHESES: WHAT CAN THEY OFFER TO EVOLUTIONARY ECOLOGISTS?}

The main advantage of using odonates lies in their practical properties for observing the genital interactions during copulation. In this extent, current ideas of the co-evolution between the sexes can be examined. Two avenues can be explored.

(1) The role of each sex in the conflict of interests for control of reproduction. Two current schools of thought are now in vogue: sexual conflict in which male adaptations may override any female filter (reviewed in Chapman et al., 2003), and cryptic female choice (Eberhard, 1996). These schools differ in the fitness consequences of mating for females. The sexual conflict hypothesis indicates that females suffer fitness costs of mating with males with more elaborated courting traits, whilst cryptic female choice suggests that, on the contrary, females gain in having more highly successful offspring from mating with such males. Recent studies in two species of insects have provided strong evidence that both sexes are co-evolving, for which it has been implied that females may suffer a fitness cost of mating (reviewed by Chapman et al., 2003). Although further evidence from other species are needed to see how generalized these patterns are, lamentably the information provided by these few studies have been used too extensively to interpret evolutionary outcomes in other species for which the role of sexes during reproduction are not entirely clear (Córdoba-Aguilar \& ContrerasGarduño, 2003). Odonates provide an advantage in this respect and may become an excellent subject for testing whether females gain or lose benefits from mating with superior males (i.e. males with high sperm displacement abilities). Some ideal species for this are members of the genus Ischnura whose rearing is possible under controlled conditions (Van Gossum, Sánchez-Guillén \& Cordero Rivera, in press).

(2) Genital evolution and speciation. The coevolutionary context of sexual interaction can serve as an engine for speciation (reviewed by Panhuis et al., 2001). Indeed, comparative studies have found correlations between the number of species and genital diversity in insects (e.g. Arnqvist, 1998). However, in these studies, the function of genitalia was only assumed to have been shaped by sexual selection (as supported by intraspecific studies, e.g. Córdoba-Aguilar, 1999b, 2002a). Again, odonates can be used for testing the same idea as there is firm evidence that their genitalia have been sexually selected (for a similar case but of speciation by sexual selection using non-genital characters in Anisoptera see Misof, 2002). Furthermore, local, microevolutionary processes can be studied in these insects using genitalia as the basis for evolutionary change in speciation. Supporting this point, unpublished data indicate that allopatric populations of Calopterygidae are differentiating at the 
level of genital form and function (Cordero Rivera et al., in press). Since these allopatric populations have been admitted as subspecies and this distinction is partly based on differences in sexually selected traits, it seems that sexual selection may be speeding up speciation.

\section{CONCLUDING REMARKS}

Odonates are a group in which copulatory mechanisms are relatively well understood. In general, males have evolved the ability to displace stored sperm and for this they use a variety of structural and behavioural adaptations. But the situation is not straightforward because females have evolved the ability to bias fertilization decisions using different behavioural, structural and physiological mechanisms. The presence of these adaptations in both sexes strongly suggests that males and females have been co-evolving to retain control over stored sperm. In fact, studies in some genera such as Calopteryx and Ischnura provide some evidence of this. This perspective should change traditional views of this group such as a passive female role in the evolution of male sperm-manipulation abilities (for a similar claim see, for example, Fincke et al., 1997). However, we are still far from understanding what drives females to evolve such sperm-control adaptations and multiple mating. We have suggested here a number of possible benefits. All of the possibilities outlined have been, however, little studied. Future studies should address the 'female point of view' to conclude to what extent females have played a role in the evolution of male sperm displacement.

\section{Acknowledgements}

We thank Academic Press for permission to use the drawings of Fig. 5. ACA was financially supported by a grant from FOMES (Fondo para el Mejoramiento de la Educación Superior-Secretaría de Educación Pública) and by a visiting grant from the Universidade de Vigo. ACR was supported by research grants from the Spanish Ministry of Science and Technology (PB97-0379 and BOS2001-3642). We thank Jesús Méndez for his help to obtain SEM pictures.

\section{REFERENCES}

Adams, J. A. \& Herman, T. H. (1991). A comparison of the male genitalia of three Calopteryx species (Odonata: Calopterygidae). Can. J. Zool. 69: 1164-1170.

Alexander, R. D., Marshall, D. C. \& Cooley, J. R. (1997). Evolutionary perspectives on insect mating. In The evolution of mating systems in insects and arachnids: 4-41. Choe, J. C. \& Crespi, B. J. (Eds). Cambridge: Cambridge University Press.

Andrés, J. A. \& Cordero Rivera, A. (2000). Copulation duration and fertilization success in a damselfly: an example of cryptic female choice? Anim. Behav. 59: 695-703.
Andrew, R. J. \& Tembhare, D. B. (1996). The post-ovarian genital complex in the damselfly, Ischnura aurora aurora (Brauer) (Insecta: Odonata). J. Adv. Zool. 17: 93-97.

Arnqvist, G. (1998). Comparative evidence for the evolution of genitalia by sexual selection. Nature (Lond.) 393: 784-785.

Arnqvist, G. \& Nilsson, T. (2000). The evolution of polyandry: multiple mating and female fitness in insects. Anim. Behav. 60: $145-164$.

Artiss, T. (2001). Structure and function of male genitalia in Libellula, Ladona and Plathemis (Anisoptera: Libellulidae). Odonatologica 30: 13-27.

Birkhead, T. R. \& Møller, A. P. (1998). Sperm competition and sexual selection. San Diego: Academic Press.

Brown, W. D., Crespi, B. J. \& Choe, J. C. (1997). Sexual conflict and the evolution of mating systems. In The evolution of mating systems in insects and arachnids: $352-377$. Choe, J. C. \& Crespi, B. J. (Eds). Cambridge: Cambridge University Press.

Chapman, T., Arnqvist, G., Bangham, J. \& Rowe, L. (2003). Sexual conflict. Trends Ecol. Evol. 18: 41-47.

Cooper, G., Miller, P. L. \& Holland, P. W. H. (1996). Molecular genetic analysis of sperm competition in the damselfly Ischnura elegans (Vander Linden). Proc. R. Soc. Lond. B Biol. Sci. 263: 1343-1349.

Corbet, P. S. (1999). Dragonflies. Behaviour and ecology of Odonata. Colchester: Harley Books.

Cordero, A. (1989). Reproductive behaviour of Ischnura graellsii (Rambur) (Zygoptera: Coenagrionidae). Odonatologica 18: 237_ 244.

Cordero, A. (1990). The adaptive significance of the prolonged copulations of the damselfly, Ischnura graellsii (Odonata: Coenagrionidae). Anim. Behav. 40: 43-48.

Cordero, A. (1999). Forced copulations and female contact guarding at high male density in a calopterygid damselfly. $J$. Insect Behav. 12: 27-37.

Cordero, A. \& Andrés, J. A. (1999). Lifetime mating success, survivorship and synchronized reproduction in the damselfly Ischnura pumilio (Odonata: Coenagrionidae). Int. J. Odonatol. 2: $105-114$

Cordero, A. \& Miller, P. L. (1992). Sperm transfer, displacement and precedence in Ischnura graellsii (Odonata: Coenagrionidae). Behav. Ecol. Sociobiol. 30: 261-267.

Cordero, A., Santolamazza Carbone, S. \& Utzeri, C. (1995). Male disturbance, repeated insemination and sperm competition in the damselfly Coenagrion scitulum (Zygoptera: Coenagrionidae). Anim. Behav. 49: 437-449.

Cordero Rivera, A. (2002). Influencia de la selección sexual sobre el comportamiento reproductor de los Odonatos. In Evolución: la base de la biología: 497-508, Soler, M. (Ed.). Granada: Proyecto Sur.

Cordero Rivera, A. \& Andrés, J. A. (2002). Male coercion and convenience polyandry in a calopterygid damselfly (Odonata). J. Insect Sci. 2: 14. Available online: insectscience. org/2.14

Cordero Rivera, A., Andrés, J. A., Córdoba-Aguilar, A. \& Utzeri, C. (in press). Post-mating sexual selection: allopatric evolution of sperm competition mechanisms and genital morphology in calopterygid damselflies (Insecta: Odonata). Evolution.

Córdoba-Aguilar, A. (1992). Comportamiento reproductivo y policromatismo en Ischnura denticollis Burmeister (Zygoptera: Coenagrionidae). Bull. Am. Odonatol. 1: 57-64.

Córdoba-Aguilar, A. (1993). Cambios de coloración en adultos de Hetaerina cruentata Rambur (Odonata: Calopterygidae). Brenesia 39-40: 181-183.

Córdoba-Aguilar, A. (1999a). Copulation and the evolution of genital morphology in the damselfy Calopteryx haemorrhoidalis asturica. Unpublished $\mathrm{PhD}$ thesis, University of Sheffield.

Córdoba-Aguilar, A. (1999b). Male copulatory sensory stimulation induces female ejection of rival sperm in a damselfly. Proc. $R$. Soc. Lond. B Biol. Sci. 266: 779-784. 
Córdoba-Aguilar, A. (2000). Reproductive behaviour of the territorial damselfly Calopteryx haemorrhoidalis asturica Ocharan (Zygoptera: Calopterygidae). Odonatologica 29: 295-305.

Córdoba-Aguilar, A. (2001). Sperm displacement ability in the damselfly Calopteryx haemorrhoidalis asturica Ocharan: no effect of male age, territorial status, copulation duration and syn-copulatory behaviour (Zygoptera: Calopterygidae). Odonatologica 30: 372-380.

Córdoba-Aguilar, A. $(2002 a)$. Sensory trap as the mechanism of sexual selection in a damselfly genital trait (Insecta: Calopterygidae). Am. Nat. 160: 594-601.

Córdoba-Aguilar, A. (2002b). Wing pigmentation in territorial male damselflies, Calopteryx haemorrhoidalis: a possible role to sexual selection. Anim. Behav. 63: 759-766.

Córdoba-Aguilar, A. (2003a). Male and female genitalia and a reconstruction of copulatory and fertilization events in Calopteryx haemorrhoidalis (Zygoptera: Calopterygidae). Odonatologica 32: 205-214.

Córdoba-Aguilar, A. $(2003 b)$. Predicting mechanisms of sperm displacement based on genital morphometrics in the Calopterygidae (Odonata). J. Insect. Behav. 16: 153-167.

Córdoba-Aguilar, A., Salamanca, J. C. \& Lopezaraiza-Mikel, M. (2003). Female reproductive decisions and parasite burden in a calopterygid damselfly (Insecta: Odonata). Anim. Behav. 66: $81-87$.

Córdoba-Aguilar, A. \& Contreras-Garduño, J. (2003). Sexual conflict. Trends Ecol. Evol. 18: 439-440.

Eberhard, W. G. (1996). Female control: sexual selection by cryptic female choice. Princeton: Princeton University Press.

Fincke, O. M. (1984a). Giant damselflies in a tropical forest: reproductive biology of Megaloprepus coerulatus with notes on Mecistogaster (Zygoptera: Pseudostigmatidae). Adv. Odonatol. 2: 13-27.

Fincke, O. M. (1984b). Sperm competition in the damselfly Enallagma hageni Walsh (Odonata: Coenagrionidae): benefits of multiple mating to males and females. Behav. Ecol. Sociobiol. 14: $235-240$.

Fincke, O. M. (1986). Underwater oviposition in a damselfly (Odonata: Coenagrionidae) favors male vigilance, and multiple mating by females. Behav. Ecol. Sociobiol. 18: 405-412.

Fincke, O. M. (1987). Female monogamy in the damselfly Ischnura verticalis Say (Zygoptera: Coenagrionidae). Odonatologica 16: 129-143.

Fincke, O. M. (1992). Consequences of larval ecology for territoriality and reproductive success of a neotropical damselfly. Ecology 73: 449-462.

Fincke, O. M. (1997). Conflict resolution in the Odonata: implications for understanding female mating patterns and female choice. Biol. J. Linn. Soc. 60: 201-220.

Fincke, O. M., Waage, J. K. \& Koenig, W. D. (1997). Natural and sexual selection components of odonate mating patterns. In The evolution of mating systems in insects and arachnids: 58-74. Choe, J. C \& Crespi, B. J. (Eds). Cambridge: Cambridge University Press.

Fisher, R. A. (1930). The genetical theory of natural selection. Oxford: Dover.

González-Soriano, E. \& Córdoba-Aguilar, A. (2003). Sexual behaviour in Paraphlebia quinta Calvert (Zygoptera: Megapodagrionidae): male dimorphism and a possible example of odonate female control. Odonatologica 32: 345-353.

Grieve, E. G. (1937). Studies on the biology of the damselfly Ischnura verticalis Say, with notes on certain parasites. Entomol. Am. 17: 121-153.

Hadrys, H., Schierwater, B., Dellaporta, S. L., DeSalle, R. \& Buss, L. W. (1993). Determination of paternity in dragonflies by random amplified polymorphic DNA fingerprints. Mol. Ecol. 2: 79-87.

Hooper, R. E. (1994). Sexual selection in a damselfly: female perspectives. Unpublished $\mathrm{PhD}$ thesis, University of Sheffield.
Hooper, R. E. \& Siva-Jothy, M. T. (1996). Last male sperm precedence in a damselfly demonstrated by RAPD profiling. Mol. Ecol. 5: 449-452.

Hooper, R. E., Tsubaki, Y. \& Siva-Jothy, M. T. (1999). Expression of a costly secondary sexual trait is correlated with age and condition in a damselfly with two male morphs. Physiol. Entomol. 24: 364-369.

Johnson, C. (1961). Breeding behaviour and oviposition in Hetaerina americana (Fabricius) and H. titia (Drury) (Odonata: Agriidae). Can. Entomol. 93: 260-266.

Keller, L. \& Reeve, H. K. (1995). Why do females mate with multiple males? The sexually selected sperm hypothesis. $A d v$. Stud. Behav. 24: 291-315.

Kirkton, S. D. \& Schultz, T. D. (2001). Age-specific behavior and habitat selection of adult male damselflies, Calopteryx maculata (Odonata: Calopterygidae). J. Insect Behav. 14: 545-556.

Kuhn, J. (1989). Spermienkonkurrenz bei mitteleuropäischen Zygoptera - eine Übersicht. Verh. West dtsch Entomol. Tag 1988: 174-201.

Lindeboom, M. (1998). Post-copulatory behaviour in Calopteryx females (Insecta, Odonata, Calopterygidae). Int. J. Odonatol. 1: $175-184$.

McVey, M. E. \& Smittle, B. J. (1984). Sperm precedence in the dragonfly Erythemis simplicicollis. J. Insect Physiol. 30: 619628 .

Michiels, N. K. (1989). Morphology of male and female genitalia in Sympetrum danae (Sulzer), with special reference to the mechanism of sperm removal during copulation (Anisoptera: Libellulidae). Odonatologica 18: 21-31.

Michiels, N. K. (1992). Consequences and adaptive significance of variation in copulation duration in the dragonfly Sympetrum danae. Behav. Ecol. Sociobiol. 29: 429-435.

Michiels, N. K \& Dhondt, A. A. (1988). Direct and indirect estimates of sperm precedence and displacement in the dragonfly Sympetrum danae (Odonata: Libellulidae). Behav. Ecol. Sociobiol. 23: 257-263.

Michiels, N. K. \& Dhondt, A. A. (1991). Sources of variation in male mating success and female oviposition rate in a non-territorial dragonfly. Behav. Ecol. Sociobiol. 29: 17-25.

Miller, P. L. (1981). Functional morphology of the penis of Celithemis eponina (Drury) (Anisoptera: Libellulidae). Odonatologica 10: 293-300.

Miller, P. L. (1984). The structure of the genitalia and the volumes of sperm stored in male and female Nesciothemis farinosa (Foerster) and Orthetrum chrysostigma (Burmeister) (Anisoptera: Libellulidae). Odonatologica 13: 415428.

Miller, P. L. (1987a). An examination of the prolonged copulations of Ischnura elegans (Vander Linden) (Zygoptera: Coenagrionidae). Odonatologica 16: 37-56.

Miller, P. L. (1987b). Sperm competition in Ischnura elegans (Vander Linden) (Zygoptera: Coenagrionidae). Odonatologica 16: 201-207.

Miller, P. L. (1989). Possible functions of the subgenital plates of female libellulid dragonflies (Anisoptera: Libellulidae). $A d v$. Odonatol. 4: 57-71.

Miller, P. L. (1990). Mechanisms of sperm removal and sperm transfer in Orthetrum coerulescens (Fabricius) (Odonata: Libellulidae). Physiol. Entomol. 15: 199-209.

Miller, P. L. (1991). The structure and function of the genitalia in the Libellulidae (Odonata). Zool. J. Linn. Soc. 102: 4373.

Miller, P. L. (1995). Sperm competition and penis structure in some libellulid dragonflies (Anisoptera). Odonatologica 24: 63-72.

Miller, P. L. \& Miller, C. A. (1981). Field observations on copulatory behaviour in Zygoptera, with an examination of the structure and activity of male genitalia. Odonatologica 10: 201218. 
Miller, P. L. \& Miller, A. K. (1989). Post-copulatory 'resting' in Orthetrum coerulescens (Fabricius) and some other Libellulidae: time for 'sperm handling'? Odonatologica 18: 33-41.

Misof, B. (2002). Diversity of Anisoptera (Odonata): infering speciation processes from patterns of morphological diversity. Zoology 105: 355-365.

Misof, B., Anderson, C. L. \& Hadrys, H. (2000). A phylogeny of the damselfly genus Calopteryx (Odonata) using mitochondrial 16S rDNA markers. Mol. Phylogenet. Evol. 15: 5-14.

Naraoka, H. (1986). Studies on the ecology of the damselfly Cercion sieboldii Selys (Coenagrionidae, Odonata) in Aomoripref., northern Japan. 2. Mating behaviour. New Entomol. 35: $7-16$.

Naraoka, H. (1994). Diurnal rhythm of the damselfly, Ischnura asiatica Brauer (Coenagrionidae, Odonata) (2) Sperm displacement. Gekkan-Mushi 279: 18-21.

Naraoka, H. (1997). Reproductive behavior of Sympecma paedisca paedisca (Odonata, Lestidae). New Entomol. 46: 20-25.

Nuyts, E. \& Michiels, N. K. (1996). High last-male sperm precedence despite unfavourable positioning of sperm in the bursa copulatrix of Sympetrum danae (Sulzer) (Anisoptera: Libellulidae). Odonatologica 25: 79-82.

Panhuis, T. A., Butlin, R., Zuk, M. \& Tregenza, T. (2001). Sexual selection and speciation. Trends Ecol. Evol. 16: 364-371.

Parker, G. A. (1970). Sperm competition and its evolutionary consequences in the insects. Biol. Rev. 45: 525-567.

Parker, G. A. (1984). Sperm competition and the evolution of animal mating strategies. In Sperm competition and the evolution of animal mating systems: 2-55. Smith, R. L. (Ed.). Orlando: Academic Press.

Perry, S. J. \& Miller, P. L. (1991). The duration of the stages of copulation in Enallagma cyathigerum (Charpentier) (Zygoptera: Coenagrionidae). Odonatologica 20: 349-356.

Pfau, H. K. (1971). Struktur und Funktion des sekundären Kopulationsapparates der Odonaten (Insecta, Palaeoptera), ihre Wandlung in der Stammesgeschichte und Bedeutung für die adaptive Entfaltung. Z. Morphol. Tiere 70: 281-371.

Rice, W. R. (1996). Sexually antagonistic male adaptation triggered by experimental arrest of female evolution. Nature (Lond.) 381 : 232-234.

Ridley, M. (1988). Mating frequency and fecundity in insects. Biol. Rev. 63: 509-549.

Robinson, J. V. \& Novak, K. L. (1997). The relationship between mating system and penis morphology in ischnuran damselflies (Odonata: Coenagrionidae). Biol. J. Linn. Soc. 60: 187-200.

Sawada, K. (1995). Male's ability of sperm displacement during prolonged copulations in Ischnura senegalensis (Rambur) (Zygoptera: Coenagrionidae). Odonatologica 24: 237-244.

Sawada, K. (1998). Sperm precedence in the damselfly Ischnura senegalensis (Rambur): is prolonged copulation advantageous to sperm precedence (Zygoptera: Coenagrionidae)? Odonatologica 27: $425-431$

Simmons, L. W. (2001). Sperm competition and its evolutionary consequences in the insects. Princeton: Princeton University Press.

Simmons, L. W. \& Siva-Jothy, M. T. (1998). Sperm competition in insects: mechanisms and the potential for selection. In Sperm competition and sexual selection: 341-434. Birkhead, T. R. \& Møller, A. P. (Eds). San Diego: Academic Press.

Siva-Jothy, M. T. (1984). Sperm competition in the family Libellulidae (Anisoptera) with special reference to Crocothemis erythraea (Brullé) and Orthetrum cancellatum (L.). Adv. Odonatol. 2: 195-207.

Siva-Jothy, M. T. (1987a). The structure and function of the female sperm-storage organs in libellulid dragonflies. J. Insect Physiol. 33: $559-567$.

Siva-Jothy, M. T. (1987b). External and internal genital structures in a gynandromorph Onychogomphus uncatus (Charp.) (Anisoptera: Gomphidae). Odonatologica 16: 307-310.
Siva-Jothy, M. T. (1987c). Variation in copulation duration and the resultant degree of sperm removal in Orthetrum cancellatum (L.) (Libellulidae: Odonata). Behav. Ecol. Sociobiol. 20: 147-151.

Siva-Jothy, M. T. (1988). Sperm 'repositioning' in Crocothemis erythraea, a libellulid with a brief copulation. J. Insect Behav. 1: $235-245$

Siva-Jothy, M. T. (1999). Male wing pigmentation may affect reproductive success via female choice in a calopterygid damselfly (Zygoptera). Behaviour 136: 1365-1377.

Siva-Jothy, M. T. (2000). A mechanistic link between parasite resistance and expression of a sexually selected trait in a damselfly. Proc. R. Soc. Lond. B Biol. Sci. 267: 2523-2527.

Siva-Jothy, M. T., Gibbons, D. W. \& Pain, D. (1995). Female oviposition-site preference and egg hatching success in the damselfly Calopteryx splendens xanthostoma. Behav. Ecol. Sociobiol. 37: 39-44.

Siva-Jothy, M. T. \& Hooper, R. E. (1995). The disposition and genetic diversity of stored sperm in females of the damselfly Calopteryx splendens xanthostoma (Charpentier). Proc. R. Soc. Lond. B Biol. Sci. 259: 313-318.

Siva-Jothy, M. T. \& Hooper, R. E. (1996). Differential use of stored sperm during oviposition in the damselfly Calopteryx splendens xanthostoma (Charpentier). Behav. Ecol. Sociobiol. 39: 389-393.

Siva-Jothy, M. T. \& Tsubaki, T. (1989). Variation in copulation duration in Mnais pruinosa pruinosa Selys (Odonata: Calopterygidae) 1. Alternative mate-securing tactics and sperm precedence. Behav. Ecol. Sociobiol. 24: 39-45.

Siva-Jothy, M. T. \& Tsubaki, Y. (1994). Sperm competition and sperm precedence in the dragonfly Nanophya pygmaea. Physiol. Entomol. 19: 363-366.

Smith, R. L. (1984). Sperm competition and the evolution of animal mating systems. Orlando: Academic Press.

Srivastava, V. K. \& Srivastava, B. K. (1986). Morphology of the male reproductive organs of Enallagma parvum Selys (Zygoptera: Coenagrionidae). Proc. Natl Acad. Sci. India 56: 13-19.

Thompson, D. J. (1990). On the biology of the damselfly Nososticta kalumburu Watson \& Theischinger (Zygoptera: Protoneuridae) Biol. J. Linn. Soc. 40: 347-356.

Thornhill, R. \& Alcock, J. (1983). The evolution of insect mating systems. Cambridge, MA: Harvard University Press.

Tregenza, T. \& Wedell, N. (2002). Polyandrous females avoid costs of inbreeding. Nature (Lond.) 415: 71-73.

Trivers, R. L. (1972). Parental investment and sexual selection. In Sexual selection and the descent of man 1871-1971: 136-179. Campbell, B. (Ed.). Chicago: Aldine.

Trueman, J. (2001). Evolutionary riddles. In Dragonflies of the world: 185-190. Silsby, J. (Ed.). London: British (Natura History) Museum.

Ubukata, H. (1984). Intra-male sperm translocation and copulatory behaviour in the dragonfly, Cordulia anenea amuriensis Selys (Odonata: Corduliidae). J. Hokkaido Univ. Educ. 35: 43-52.

Utzeri, C. \& Sorce, G. (1988). Sostituzione dello sperma in Coenagrion scitulum (Rambur) (Odonata: Coenagrionidae). Atti XV Congr. Nazionale Ital. Entomol. L'Aquila 1988: 723-729.

Van Gossum, H., Sánchez-Guillén, R. A. \& Cordero Rivera, A. (in press). Observations on rearing damselflies under laboratory conditions. Anim. Biol.

Waage, J. K. (1979). Dual function of the damselfly penis: sperm removal and transfer. Science 203: 916-918.

Waage, J. K. (1982a). Sexual selection, ESS theory and insect behaviour: some examples from damselflies (Odonata). Fla Entomol. 66: 19-31.

Waage, J. K. (1982b). Sperm displacement by male Lestes vigilax Hagen (Zygoptera: Lestidae). Odonatologica 11: 201209.

Waage, J. K. (1984). Sperm competition and the evolution of odonate mating systems. In Sperm competition and the evolution of animal mating systems: 251-290. Smith, R. L. (Ed.). Orlando: Academic Press. 
Waage, J. K. (1986a). Evidence for widespread sperm displacement ability among Zygoptera (Odonata) and the means for predicting its presence. Biol. J. Linn. Soc. 28: 285-300.

Waage, J. K. (1986b). Sperm displacement by two libellulid dragonflies with disparate copulation durations (Anisoptera). Odonatologica 15: 429-444.

Waage, J. K. (1988). Reproductive behaviour of the damselfly Calopteryx dimidiata Burmeister (Zygoptera: Calopterygidae). Odonatologica 17: 365-378.

Watanabe, M. \& Adachi, Y. (1987). Fecundity and oviposition pattern in the damselfly Copera annulata (Selys) (Zygoptera: Platycnemididae). Odonatologica 16: 85-92.
Williams, G. C. (1975). Sex and evolution. Princeton: Princeton University Press.

Wolf, L. L., Waltz, E. C., Wakeley, K. \& Klockowski, D. (1989). Copulation duration and sperm competition in white-faced dragonflies (Leucorrhinia intacta, Odonata: Libellulidae). Behav. Ecol. Sociobiol. 24: 63-68.

Yasui, Y. (1998). The 'genetic' benefits of female multiple mating reconsidered. Trends Ecol. Evol. 13: 246250

Zeh, J. A. \& Zeh, D. W. (2001). Reproductive mode and the genetic benefits of polyandry. Anim. Behav. 61: 10511063. 